\title{
Marcin Muszyński (red.), Międzypokoleniowe uczenie się, Wy- dawnictwo Uniwersytetu Łódzkiego, Łódź 2014, ss. 175
}

Proces starzenia się światowej populacji pociąga za sobą nieodwracalne konsekwencje cywilizacyjne, kulturowe, ekonomiczne, polityczne. Jednakże mimo to współczesny świat skupiony jest przede wszystkim na agresywnie eksponowanym przez media kulcie młodości, piękna oraz sukcesu materialnego. Utrzymanie młodszego wyglądu jest obecnie często punktem honoru, już nie tylko kobiet, ale coraz częściej również mężczyzn. Natomiast starzenie odbierane jest w głównej mierze negatywnie, kojarzone z zahamowaniem lub brakiem aktywności życiowej, aspiracji, pasji i celów oraz smutkiem. Aby zmienić ten stereotypowy sposób myślenia niezbędna jest umiejętnie prowadzona, wielokierunkowa edukacja międzypokoleniowa, która uświadomi jednostkom w różnym wieku, że bez względu na metrykę ludzie są sobie potrzebni, że mają sobie wiele do powiedzenia, że mogą się wiele od siebie nauczyć.

Problematyce międzypokoleniowego uczenia się, które odbywa się przede wszystkim na gruncie edukacji nieformalnej, poświęcona została książka pod redakcją Marcina Muszyńskiego, zatytułowana Międzypokoleniowe uczenie się. Publikacja ta jest zbiorem trzynastu artykułów, których analiza uzmysławia złożoność, wieloaspektowość i uniwersalność poruszanej w nich tematyki. Ma ona na celu umożliwienie czytelnikowi świadomej percepcji międzypokoleniowego uczenia się przez zarysowanie jego podstaw teoretycznych i metodologicznych.

Marcin Muszyński, w otwierającym książkę tekście, pt. Międzypokoleniowe uczenie się - wprowadzenie, charakteryzuje pojęcie „międzypokoleniowego uczenia się". Podkreśla, że międzypokoleniowe uczenie się zachodzi w większości sytuacji społecznych, czyli jest społecznie wszechobecne, a przez to powszechnie niezauważalne, wręcz „niewidzialne”. W artykule badacz zauważa, że w świecie nauki szeroko rozumiana międzypokoleniowość 
funkcjonuje w wielu kontekstach i łączona jest m.in. z redystrybucją wypracowanych dóbr i usług, programami kształcenia gerontologicznego, analizami porównawczymi z zakresu nierówności społecznych ze względu na wiek, historią mówioną, transmisją antyspołecznych zachowań. Nakreśla skutki ciągle powiększających się różnic pokoleniowych i ukazuje międzynarodowe działania mające na celu przeciwdziałanie im. Prezentuje podstawowe założenia międzypokoleniowego uczenia się, które jego zdaniem ma znaczący wpływ na zwiększenie kapitału społecznego oraz umożliwia pełniejszy rozwój jednostki przez otwarcie jej na Innego i umożliwienie konstruowania różnych strategii komunikowania się. Zarysowuje teoretyczne i metodologiczne ramy międzypokoleniowego uczenia się, koncentrując się na koncepcji Roberta i Paris Strom, w której nacisk kładziony jest na wskazanie: najlepszych warunków do zaistnienia międzypokoleniowego uczenia się, korzyści wynikających z obustronnego uczenia się osób w różnym wieku, metod podnoszących efektywność uczenia się w szkole i rodzinie. Wyznacza także drogę instytucjonalizacji międzypokoleniowego uczenia się biegnącą od działań mających swój wyraz w codzienności, przez różnorodne programy, po konstruowanie opierających się na nim sformalizowanych programów kształcenia.

Dążąc do ukazania istoty międzypokoleniowego uczenia się ludzi dorosłych, Marcin Rojek, w artykule Międzypokoleniowe uczenie się w kontekście badania historii życia, konfrontuje różnorodne sposoby rozumienia pojęcia „uczenie się” z założeniami koncepcji pokoleniowości Karla Mannheima. Jako przykład badań nad międzypokoleniowym uczeniem się badacz prezentuje zrealizowany w Wielkiej Brytanii, w latach 2004-2008, projekt Improving Learning through the Lifecourse. Learning Lives, który oparty został na analizie historii życia i interpretacji jego przebiegu. Rojek podkreśla, że źródłem bazującego na dobrowolności międzypokoleniowego uczenia się są międzypokoleniowe relacje, które umożliwiają zdobycie nowej wiedzy, umiejętności i postaw, wykraczających poza oficjalne programy nauczania, poszerzających możliwości percepcyjne oraz otwierających na siebie i innych.

W kolejnych sześciu opublikowanych w książce tekstach ich autorzy koncentrują się na ukazaniu wybranych aspektów tradycyjnie pojmowanego procesu międzypokoleniowego uczenia się. Zakładają oni przede wszystkim uczenie się osób młodszych od osób starszych, ale nie wykluczają istnienia równoczesnego przekazu w przeciwnym kierunku. Lucyna Telka buduje swoje rozważania wokół wprowadzonego do pedagogiki społecznej przez Helenę Radlińską pojęcia „wyobraźnia społeczna”. Zagadnienie międzypokoleniowego uczenia się rozpatruje z perspektywy refleksyjnego wychowaw- 
cy, który aby zasłużyć na to miano, musi według niej uwzględniać w swoich działaniach edukacyjnych kontekst, w jakim są one podejmowane, a przede wszystkim sygnały wysyłane przez ich podmiot, czyli nawet najmłodszych podopiecznych/uczniów. Problematyce międzypokoleniowego uczenia się, będącego wynikiem refleksyjnego dialogu dziadków i wnuków, poświęca swój artykuł Ryszard Kałużny. Badacz podkreśla, że tego typu proces edukacyjny cechuje wzajemność, bilateralność, a płynące z niego korzyści dotyczyć mogą wszystkich jego uczestników. W tekście Magdaleny Sasin zostały zaprezentowane wyniki przeprowadzonych przez nią badań empirycznych, które pozwalają badaczce wnioskować, że zachodzący w rodzinie przekaz międzypokoleniowy jest zasadniczym czynnikiem rozwoju zainteresowań (sztuką). Równocześnie autorka podkreśla, że znacząca w tej kwestii jest także transmisja międzypokoleniowa odbywająca się poza środowiskiem rodzinnym, za pośrednictwem szkoły i mediów, gdzie autorami komunikatów adresowanych do najmłodszych i młodzieży są z reguły przedstawiciele starszego pokolenia. Elżbieta Woźnicka dowodzi, że tworzenie blogów może stanowić dla seniorów znakomitą okazję do aktywnego funkcjonowania w ramach społeczeństwa informacyjnego. Pisanie internetowych pamiętników, wbrew dominacji opisanej przez Margaret Mead kultury prefiguratywnej, umożliwić może im realne oddziaływanie na młodsze pokolenia. Przedmiotem rozważań Renaty Maciejewskiej jest międzygeneracyjny przekaz tradycji funkcjonujący w dawnych społecznościach wiejskich. Małgorzata Szokalak natomiast, w artykule pt. Międzypokoleniowy dialog a wartości religijne $w$ radiowych homiliach biskupa Józefa Zawitkowskiego, zaznacza, że międzypokoleniowe uczenie się jest procesem, który towarzyszy człowiekowi przez całe jego życie może odbywać się w sposób naturalny w czasie wspólnej pracy, zabawy, rozmowy, wspólnego rozwiązywania problemów, składania świadectwa.

Następnym zagadnieniem poruszanym w recenzowanej publikacji jest pokoleniowość niemieckiej andragogiki. Hanna Solaczyk-Szwec prezentuje cztery generacje andragogów Republiki Federalnej Niemiec przez pryzmat biografii badacza reprezentatywnego dla każdej z nich. Autorka zwraca szczególną uwagę na kwestie stosunku wyłonionych przez nią naukowych pokoleń do teoretycznego i metodologicznego dorobku poprzedników.

Problematyce międzypokoleniowego uczenia się, w którym wbrew utartym regułom także osoby młodsze mogą pełnić funkcję edukatorów ludzi starszych, poświęciła swój artykuł Renata Konieczna-Woźniak. Autorka, przedstawiając wyniki badań przeprowadzonych przez siebie wśród studentów, zauważa, że we współczesnej stechnicyzowanej rzeczywistości, którą 
cechuje zmienność, młodzi ludzie nie tylko dostrzegają obszary deficytów kompetencji ludzi starszych, ale także są gotowi pomóc im je zniwelować. Co ważne, zdaniem badaczki współpraca starszego pokolenia, cechującego się wiedzą i doświadczeniem, z ludźmi młodymi, których atrybutem są niezbędne obecnie umiejętności i szybkie tempo uczenia, zaowocować może obopólnymi korzyściami, przyczynić się do lepszego poznania i zrozumienia, a tym samym zacieśnienia relacji międzypokoleniowych w rodzinach i poza nimi. Pozwolić może na pozbawione znamion dominacji, naprzemienne wcielanie się przedstawicieli poszczególnych pokoleń w rolę nauczających i uczących się.

W tekście autorstwa Anny Sladek zdrowie ukazane jest jako jeden z obszarów stanowiących tzw. punkt wspólny, który sprawia, że reprezentanci różnych pokoleń chcą razem spędzić czas w celu osiągnięcia jakiejś ważnej społecznie zmiany. Zdaniem badaczki eksplorowanie tej problematyki umożliwia uczenie się „(między)pokoleniowe”, czyli obejmujące oparte na autorytecie i tradycji uczenie ludzi młodych przez ludzi starszych, wychodzące naprzeciw wyzwaniom współczesności uczenie ludzi starszych przez ludzi młodych, a także opierające się na naśladownictwie uczenie się w obrębie jednego pokolenia.

Kolejnym zagadnieniem prezentowanym na łamach książki jest zależność występująca między międzypokoleniowym uczeniem się a podnoszeniem kwalifikacji w miejscu pracy. Kwestii tej poświęcone zostały dwa teksty. W pierwszym z nich, zatytułowanym Uczenie się międzypokoleniowe $w$ środowisku pracy - wybrane strategie i metody, Dorota Nawrat przybliża metody uczenia się oparte na dzieleniu się doświadczeniem, koncentrując się na mentoringu i intermentoringu. W drugim artykule Agata Matuszewska obrazuje funkcjonowanie mentoringu w przedsiębiorstwie na przykładzie łódzkiej instytucji finansowej.

Podsumowując, można stwierdzić, że recenzowana publikacja wskazuje na procesualność, heterogeniczność, wieloaspektowość i całożyciowość międzypokoleniowego uczenia się. Autorzy zawartych w niej artykułów, nakreślając metodologiczne i teoretyczne ramy międzypokoleniowego uczenia się, umiejętnie odnieśli się zarówno do powszechnie łączonych z tą problematyką twierdzeń autorstwa M. Mead (M. Sasin, A. Sladek, E. Woźnicka, R. Konieczna-Woźniak), jak i koncepcji R. i P. Strom (M. Muszyński), K. Mannheima (M. Rojek) czy Malcolma S. Knowlesa (D. Nawrat). Tym samym lektura recenzowanej książki stanowi znakomitą inspirację do dalszych intelektualnych poszukiwań związanych z międzypokoleniowym uczeniem się oraz pretekst do odkrywania i eksplorowania kolejnych obszarów zacho- 
dzenia tego procesu. Uświadamia, że w świecie, w którym dorośli przestają być jedynym źródłem wiedzy i zasad postępowania, bez upowszechniana i wprowadzania w życie założeń procesu międzypokoleniowego uczenia się opartego na zrozumieniu i wzajemności, niemożliwym będzie zniwelowanie dystansu dzielącego pokolenia. Pozwala wnioskować, że realizowanie cechujących się innowacyjnością programów międzypokoleniowego uczenia się może umożliwić wyposażenie osób w różnym wieku w wiedzę, umiejętności i postawy pozwalające na efektywniejsze/pełniejsze funkcjonowanie we współczesnym świecie.

Kinga Majchrzak 